Saudi Journal of Business and Management Studies Abbreviated Key Title: Saudi J Bus Manag Stud ISSN 2415-6663 (Print) IISSN 2415-6671 (Online) Scholars Middle East Publishers, Dubai, United Arab Emirates Journal homepage: https://saudijournals.com/sjbms

Original Research Article

\title{
The Effect of Corporate Social Responsibility on Tax Aggressiveness and Impact on Financial Performance
}

\author{
Handaya Wijaya, Hadri Mulya
}

Post-Graduation Program, Universitas Mercu Buana, Jakarta, Indonesia

\author{
DOI: $10.36348 /$ sjbms.2020.v05i09.003 \\ | Received: 02.09.2020 | Accepted: 11.09.2020 | Published: 30.09.2020 \\ *Corresponding author: Handaya Wijaya \\ Abstract
}

This study was conducted to examine the effect of corporate social responsibility on tax aggressiveness and its impact on financial performance. The sample in this study is mining companies listed on the Indonesia Stock Exchange in the 2012 2017 period. The sampling technique used in this study was purposive sampling, where in the purposive sampling sample the mining companies were selected. The analysis technique used is multiple regression analysis. The results showed that corporate social responsibility did not have a significant effect on tax avoidance, tax avoidance had a significant effect in the opposite direction on financial performance and corporate social responsibility had no significant effect on financial performance.

Keywords: Corporate Social Responsibility, Tax Aggressiveness, Financial Performance.

Copyright @ 2020: This is an open-access article distributed under the terms of the Creative Commons Attribution license which permits unrestricted use, distribution, and reproduction in any medium for non-commercial use (NonCommercial, or CC-BY-NC) provided the original author and source are credited.

\section{INTRODUCTION}

Corporate Social Responsibility or social responsibility is an interesting discussion lately. More and more companies are realizing that the main goal of the company is not only to make as much profit as possible but also to have a social responsibility towards the surrounding environment and society. Corporate Social Responsibility, which is considered by the company to be a burden, is now no longer a burden but a business necessity. The role of Corporate Social Responsibility, which used to be interpreted as voluntary donations (voluntary) and generosity (philanthropy), is now increasingly widespread due to the company's awareness that the need to synergize business interests with the surrounding environment including stakeholders, be it the environment, the surrounding community, employees, customers, creditors and so on. A good Corporate Social Responsibility program should be sustainable and sustainable, not just a subsidy program, successful Corporate Social Responsibility is not measured by the amount of funds spent but rather a Corporate Social Responsibility program that is able to minimize negative impacts and maximize the positive impact of the production process, services, products, business operations and company decisions.

Fabiola Febrinastri [1] is currently very advanced in all aspects, this progress encourages companies in the world to increase their competitive level, so that company competitiveness is not weak in the eyes of investors, shareholders, and other companies. Apart from improving the company's economy, companies must increase the level of social awareness and value of good behavior towards internal (employees) and external (community, environment) that can be realized through corporate social responsibility. Corporate Social Responsibility provides results, either directly or indirectly, on the company's finances in the future. Investors want their investment and public trust in their company to have a good image. By carrying out sustainability Corporate Social Responsibility programs, the company is expected to run well, so that this program is more accurately classified as an investment and must become the business strategy of a company. 
Yuansyah Satya [2] mining companies are known as environmental polluters. Therefore, mining companies must implement social responsibility programs in the form of programs that can minimize the impact of environmental damage from their mining business. Mining is an industry that can provide high economic benefits. Martiono Hardianto [3] assesses that many mining corporations do not understand the importance of corporate social responsibility programs for the community or the surrounding environment. So far, the mining business has always been seen as destroying the environment. Therefore he reminded the importance of associations to collaborate with the government to make mining companies aware of the importance of social responsibility. The energy and mineral resource sectors contribute significantly to state revenues. This sector accounts for nearly 30 percent, including oil, gas, minerals and coal. However, the role of Corporate Social Responsibility in this sector is different from other sectors, such as telecommunications or banking.

Other studies related to the influence of Corporate Social Responsibility on tax aggressiveness or tax avoidance show different results. Preuss [4] and Sikka [4] argue that some companies that claim to carry out Corporate Social Responsibility are still avoiding taxes. Thus, the higher the disclosure of Corporate Social Responsibility, the higher the tax avoidance will be. Faridatul, Anis Wulandari [5], Dwi Fionasari [6], Jessica and Agus Arianto [7], Triani Arofah [8] the results of this study reveal that there is no significant influence between Corporate Social Responsibility on tax aggressiveness. Elmi Rakhma [9], Ida Ayu, Ni Ketut [10] Denny, Akhmad Saebani [11] the results of this study reveal that there is a significant influence between Corporate Social Responsibility on tax aggressiveness. Marissa Yaparto, Dianne [12], Nita Dwi Aryati [13], Nanik Lestari, Novi [14] the results of the study reveal that corporate social responsibility has an effect on financial performance.

\section{LITERATURE REVIEW \\ Legitimacy Theory}

O'Donovan, in Nor Hadi [15] that legitimacy is a company management system that is oriented towards taking sides with society (society), government, individuals, and community groups. For this reason, as a system that promotes pro-society, the company's operations must be congruent with the expectations of the community. Community legitimacy to companies as something that is given and is something that companies / organizations seek. Providing legitimacy by the community to companies can only be done if the company carries out social responsibility [16].

\section{Stakeholder Theory}

The term stakeholder was first introduced by the Stanford Research Institute (RSI) in 1963 [17]. Until Freeman developed a theoretical exposition of stakeholders in 1984 in his work entitled Strategic Management.

Freeman in Ghozali and Chahriri [18] stakeholders are groups or individuals who can influence each other in the process of achieving company goals. The development of the business world requires companies to pay more attention to existing stakeholders and not only the owner or company owner. Apart from being ethical demands that are expected to bring economic benefits and added value to maintain the company's business continuity, it is from this perspective that stakeholder theory is then developed.

\section{Signaling Theory (Signaling Theory)}

Brigham and Joel F. Houston [19] Signaling Theory emphasizes the importance of an information issued by the company for an investment decision made by outsiders. An action that a company takes to provide guidance to investors about how management views the company's prospects. This signal is in the form of information about what management has done to realize the owner's wishes. Information released by the company is important, because it affects the investment decisions of parties outside the company.

\section{Corporate Social Responsibility (CSR)}

Corporate Social Responsibility is the ability of a company to be able to overcome the negative implications as a result of the company's production process, company operations and company facilities. One way to overcome these negative implications is to minimize the negative impacts caused by the production and operational processes of the company, maximize company efficiency and minimize negative practices that can affect a country's natural resources for future generations [20].

\section{Tax Aggressiveness}

According to Frank [21] tax aggressiveness is an action taken by companies to reduce taxable income through tax planning, both legal a through tax avoidance as well as illegall by tax evasion. is called tax aggressiveness. Although not all of the actions taken violated the rules, the more loopholes a company uses, the more aggressive the company is. Tax aggressiveness is a corporate strategy that is not in line with community expectations [22]. There is no universally accepted definition or measure of tax aggressiveness [20]. Hlaing [23] defines tax aggressiveness as the tax planning activity of all companies involved in reducing the effective tax rate. It can be concluded that tax aggressiveness is part of tax management in terms of tax planning. Where if it is associated with tax avoidance or evasion, tax aggressiveness planning leads to tax avoidance which is included in legal action in an effort to reduce the amount of tax that the company must pay. 


\section{Financial performance}

Companies as a form of organization generally have certain goals to be achieved. Success in achieving company goals is an achievement for company management. Performance appraisal or performance of a company is measured because it can be used as a basis for decision making, both internal and external. Financial performance is a description of the financial condition of a company that can be analyzed with financial analysis tools, so that it can be seen whether the financial condition of a company is good or not in a certain period. Measurement of financial performance is very important to ensure that company resources are used optimally and efficiently. Assessment of financial performance can be carried out by management in order to fulfill its obligations to its stakeholders and also to achieve the goals set by the company.

\section{Hypothesis}

$\mathrm{H}_{1}$ : Corporate Social Responsibility has a significant effect on Tax Aggressiveness

$\mathrm{H}_{2}$ : Tax Aggressiveness has a significant effect on Financial Performance

$\mathrm{H}_{3}$ : Corporate Social Responsibility has a significant effect on Financial Performance

\section{RESEARCH METHODS}

The population in this study are mining companies listed on the Indonesia Stock Exchange (BEI) in the 2012-2017 period. The object of this research is focused on mining companies. Mining companies are known as companies polluting the environment. Therefore, mining companies must implement social responsibility programs in the form of programs that can reduce the impact of environmental damage from their mining efforts. The total population in this study until the end of 2017 was 45 mining companies listed on the Indonesia Stock Exchange, of the total 45 mining companies, samples were taken for this study. The mining company samples were selected using purposive sampling. Purposive sampling itself is a sampling technique based on the author's own judgment / criteria by determining specific characteristics in accordance with the research objectives so that it is expected to be able to answer research problems. Based on the definition of purposive sampling above, the criteria in this study are:

a) The listing date of shares on the IDX is more than or the same as January 1, 2012.

b) Has a complete tax burden in the Financial Statement year from 2012 - 2017 (research year)

c) The company includes a Corporate Social Responsibility report in its financial statements.

\section{RESULTS AND DISCUSSION}

Table-1: Descriptive Statistical Test

\begin{tabular}{|l|l|l|l|l|l|}
\hline \multicolumn{7}{|c|}{ Descriptive Statistics } \\
\hline & $\mathrm{N}$ & Min & Max & Mean & Deviation \\
\hline CSR & 60 &, 08 &, 23 &, 1493 &, 03357 \\
\hline ETR & 60 &,- 23 &, 92 &, 3154 &, 18627 \\
\hline Tobin & 60 &, 16 & 8,12 & 1,0597 & 1,05311 \\
\hline N (listwise) & 60 & & & & \\
\hline
\end{tabular}

Based on the table, it can be seen that the Corporate Social Responsibility data shows an average value of $14.93 \%$ with a standard deviation value of $3.35 \%$. The standard deviation value is below the average value. That is, the data variation is low or there is no data gap between the lowest value of $8 \%$, which consists of PT. Eatertainment International Tbk (2014) and the highest score of $23 \%$, consisting of PT. Radiant Utama Interinco, Tbk (2016), PT. Indo Tambangraya, Tbk (2017), PT. Eatertainment International, Tbk (2014).

Effective Tax Rates data shows an average value of $31.54 \%$ with a standard deviation of $18.62 \%$. The standard deviation value is below the average value. That is, the data variation is low or there is no data gap between the lowest value of $-23 \%$, namely PT. Medco Energi Internasional, Tbk (2015) and the highest score of $92 \%$, consisting of PT. Eatertainment International, Tbk (2015) and PT. Medco Energi International, Tbk (2014).

Tobin's Q data shows an average value of $105.97 \%$ with a standard deviation value of $105.31 \%$. The standard deviation value is below the average value. That is, the data variation is low or there is no data gap between the lowest value of $16 \%$, which consists of PT Resource Alam Indonesia, Tbk (2016) and the highest value of $812 \%$, which consists of PT. Resouces Alam Indonesia, Tbk (2016) and PT. Entertainment International, Tbk (2014). 
Table-2: Multicollinearity Test

\begin{tabular}{|c|c|c|}
\hline \multirow{2}{*}{ Variable } & \multicolumn{2}{|c|}{ VIF } \\
\cline { 2 - 3 } & CSR on ETR & $\begin{array}{c}\text { CSR and ETR } \\
\text { on Tobin's Q }\end{array}$ \\
\hline CSR & 1,000 & 1,060 \\
\hline ETR & - & 1,060 \\
\hline
\end{tabular}

Based on the results in the table above, it can be seen that for all independent variables in the two models the VIF value is less than 10. Thus it can be stated that all models are declared to have no multicollinearity symptoms. So that the assumption of multicollinearity is fulfilled.

Table-3: Correlation Test of CSR to ETR

\begin{tabular}{|c|c|c|}
\hline \multicolumn{2}{|c|}{ Value DW } & Value \\
\hline$<\mathrm{dL}$ & $<1,5035$ & \multirow{5}{*}{1,924} \\
\hline $\mathrm{dL}-\mathrm{dU}$ & $1,5035-1,5849$ & \\
\hline $\mathrm{dU}-(4-\mathrm{dU})$ & $1,5849-2.4151$ & \\
\hline $\begin{array}{l}(4-d U)-(4- \\
d L)\end{array}$ & $2.4151-2.4965$ & \\
\hline$>(4-\mathrm{dL})$ & $>2.4965$ & \\
\hline
\end{tabular}

Based on the summary in the table above, the Durbin Watson (DW) value is 1.924 , where this value falls under the dU - (4-dU) criteria. Thus the residuals generated from the estimated regression equations have no autocorrelation. So that the autocorrelation assumption in the influence model of Corporate Social Responsibility on Earning Tax Ratio is fulfilled.

Table-4: Correlation Test Results of Corporate Social Responsibility and Earning Tax Ratio against Tobin's' Q

\begin{tabular}{|c|c|c|}
\hline \multicolumn{2}{|c|}{ Nilai DW } & Nilai DW \\
\hline$<\mathrm{dL}$ & $<1,5004$ & 2,022 \\
\hline $\mathrm{dL}-\mathrm{dU}$ & $1,5004-1,6452$ & \\
\hline $\mathrm{dU}-(4-\mathrm{dU})$ & $1,6452-2.3548$ & \\
\hline$(4-d U)-(4-d L)$ & $2.3548-2.4996$ & \\
\hline$>(4-d L)$ & $>2.4996$ & \\
\hline
\end{tabular}

Based on the summary in the table above, the Durbin Watson (DW) value is 2.022, where this value falls within the $\mathrm{dU}-(4-\mathrm{dU})$ criteria. Thus the residuals generated from the estimated regression equations have no autocorrelation. So that the autocorrelation assumption of the influence model of CSR and ETR on Tobins' $Q$ is fulfilled.

Table-5: Spearman's Heteroscedasticity Test

\begin{tabular}{|l|c|c|}
\hline $\begin{array}{l}\text { Independen } \\
\text { Variable }\end{array}$ & CSR on ETR & $\begin{array}{l}\text { CSR and ETR or } \\
\text { Tobin's Q }\end{array}$ \\
\hline CSR & 0,688 & 0,001 \\
\hline ETR & - & 0,021 \\
\hline
\end{tabular}

The results of testing the heteroscedasticity assumption using the Spearman correlation can be seen that the probability value generated by the CSR influence model on ETR results in a CSR probability value greater than a significant Alpha $5 \%$ or 0.05 . Thus the assumption of heteroscedasticity in the model of the effect of CSR on ETR is fulfilled. However, the probability value generated by the model of the effect of CSR and ETR on Tobin's Q produces a probability value for CSR and ETR which is smaller than the significant Alpha 5\% or 0.05 . Thus the assumption of heteroscedasticity in the model of the influence of CSR and ETR on Tobin's Q is not fulfilled so that outliers are checked, on the model of the influence of CSR and ETR on Tobin's Q.

Table-6: Results of the Spearman Model Heteroscedasticity Test After Outlier

\begin{tabular}{|l|l|}
\hline $\begin{array}{l}\text { Independen } \\
\text { Variable }\end{array}$ & Effect CSR and ETR on Tobin's Q \\
\hline CSR & 0,754 \\
\hline ETR & 0,332 \\
\hline
\end{tabular}


Testing the heteroscedasticity assumption after the outlier model of the effect of CSR and ETR on Tobin's Q has been fulfilled. This is indicated by the probability value of each independent variable> significant alpha $5 \%$ or 0.05 with the assumption that heteroscedasticity in the model of the effect of CSR and ETR on Tobin's Q has been fulfilled.

Table-7: CSR Regression Test against ETR

\begin{tabular}{|c|c|c|c|c|c|c|}
\hline \multicolumn{7}{|c|}{ Coefficients $^{\mathrm{a}}$} \\
\hline & \multirow{2}{*}{ Model } & \multicolumn{2}{|c|}{$\begin{array}{l}\text { Unstandardized } \\
\text { Coefficients }\end{array}$} & \multirow{2}{*}{$\begin{array}{c}\text { Standardized Coefficients } \\
\text { Beta }\end{array}$} & \multirow[t]{2}{*}{$\mathrm{t}$} & \multirow{2}{*}{ Sig. } \\
\hline & & $\mathrm{B}$ & Std. Error & & & \\
\hline \multirow{2}{*}{1} & (Constant) & ,447 &, 059 & & 7,576 &, 000 \\
\hline & CSR &,- 790 & ,394 &,- 278 & $-2,008$ &, 050 \\
\hline \multicolumn{7}{|c|}{ a. Dependent Variable: ETR } \\
\hline
\end{tabular}

Based on the regression equation table that can be formulated as follows:

\section{$\mathrm{Y}_{1}: \boldsymbol{\beta}_{1} \mathrm{X}_{1}+\mathrm{e}$}

ETR : 0,447 - 0,790X $X_{1}+\mathrm{e}$

From the results of testing the significance of the data, the results obtained include:
1. The Corporate Social Responsibility variable has a coefficient value of 0.790 in a negative direction, this shows that if the Corporate Social Responsibility variable decreases by $1 \%$ it will cause a decrease in the value of Taxes Effective Rates.

Table-8: CSR, ETR Regression Test Against Tobins'Q

\begin{tabular}{|c|c|c|c|c|c|c|}
\hline \multicolumn{2}{|c|}{ Model } & \multicolumn{2}{c|}{$\begin{array}{c}\text { Unstandardized } \\
\text { Coefficients }\end{array}$} & $\begin{array}{c}\text { Standardized } \\
\text { Coefficients }\end{array}$ & \multirow{2}{*}{ T } & \multirow{2}{*}{ Sig. } \\
\cline { 3 - 7 } & B & Std. Error & Beta & & \\
\hline \multirow{3}{*}{1} & (Constant) & 1,161 &, 263 & & 4,421 &, 000 \\
\cline { 2 - 7 } & CSR &, 619 & 1,760 &, 045 &, 352 &, 726 \\
\cline { 2 - 7 } & ETR & $-1,040$ &, 335 &,- 400 & $-3,105$ &, 003 \\
\hline \multicolumn{7}{|c|}{ a. Dependent Variable: Tobinsq } \\
\hline
\end{tabular}

Based on the table above, the regression equation that can be formulated is as follows:

$\mathrm{Y}_{2}: \boldsymbol{\alpha}+\boldsymbol{\beta}_{2} \mathrm{X}_{2}+\boldsymbol{\beta}_{3} \mathrm{X}_{3}+\mathrm{e}$

Tobins : $1,161+0,619 X_{2}-1,041 X_{2}+e$

From the results of testing the significance of the data, the results obtained include:

1. The Corporate Social Responsibility variable has a coefficient value of 0.619 in a positive direction, this shows that if the Corporate Social Responsibility variable increases by $1 \%$ it will cause an increase in the value of Tobins'Q received by the coefficient.

2. The Effective Taxes Rates variable has a coefficient value of 1.040 in a negative direction, this shows that if the Effective Taxes Rates variable decreases by $1 \%$, it will cause an increase in the value of the received Tobins'Q coefficient.

Table-9: Test of the Coefficient of Determination $\left(\mathbf{R}^{2}\right)$

\begin{tabular}{|c|l|}
\hline Model & $\boldsymbol{R}^{\mathbf{2}}$ \\
\hline CSR on ETR $\left(\boldsymbol{R}_{\mathrm{FTR}}^{2}\right)$ & 0,078 \\
\hline CSR and ETR on Tobin's Q $\left(\boldsymbol{R}_{\mathrm{T}}^{2}\right)$ & 0,154 \\
\hline $\mathbf{R}_{\mathrm{m}}^{2}=\mathbf{1}-\left(\left(\mathbf{1}-\boldsymbol{R}_{\mathrm{ETR}}^{2}\right) *\left(\mathbf{1}-\boldsymbol{R}_{\mathrm{T}}^{2}\right)\right)$ \\
$\mathbf{R}_{\mathrm{m}}^{2}=\mathbf{1}-((\mathbf{1}-\mathbf{0 , 0 7 8}) *(\mathbf{1}-\mathbf{0 , 1 5 4}))=\mathbf{0 , 2 1 9 9 9}$ \\
\hline
\end{tabular}

1. The R-square in the model of the effect of CSR on ETR is 0.078 or $7.8 \%$. This can indicate that the diversity of the Effective Tax Rates variable can be explained by the Corporate Social Responsibility variable of $7.8 \%$, or in other words the contribution of the Corporate Social Responsibility variable to the Effective Tax Rates is $7.8 \%$, while the remaining $92.2 \%$ represents the contribution of other variables which are not discussed in this study.
2. The R-square model of the influence of Corporate Social Responsibility and Effective Tax Rates on Tobin's Q is 0.154 or $15.4 \%$. This can indicate that the diversity of Tobin's $Q$ variables can be explained by the Corporate Social Responsibility and Effective Tax Rates variables of $15.4 \%$, or in other words the contribution of the Corporate Social Responsibility and Effective Tax Rates variables to Tobins'Q is $15.4 \%$, while the remaining $84.6 \%$ is the contribution 
of other variables not discussed in this study.

3. The total coefficient of determination is 0.21999 or $21.999 \%$. This can indicate that the contribution of the total influence of the Corporate Social Responsibility variable and tax aggressiveness both directly and indirectly to financial performance is $21.999 \%$, while the remaining $78.001 \%$ is the contribution of other variables not discussed in this study.

\section{DISCUSSION}

The Influence of Corporate Social Responsibility on Tax Aggressiveness

The test results reveal that there is no significant influence between Corporate Social Responsibility on Tax Aggressiveness.

Corporate Social Responsibility for mining companies is something that is an obligation as regulated in law. Therefore, it is proper and proper for mining companies to rehabilitate forests or areas affected by pollution and environmental damage caused by their production activities. The amount and rules of CSR itself as mandated by law have been regulated by the taxation law, so that it does not have a significant effect on tax aggressiveness.

If it is related to the theory of legitimacy, this has a connection, where mining companies are obliged to carry out Corporate Social Responsibility that is oriented towards the community, government, individuals and community groups. By carrying out social responsibility, the company will find it easier to get legitimacy from the community which in the end will have a positive impact on the company, such as smooth running of production activities, not getting rejection from the community and so on.

The results of this study are in line with the research of Faridatul, Anis Wulandari [5], Dwi, Enni Savitri [6], Jessica and Agus Arianto [7], Triani Arofah [8], the results of this study reveal that there is no significant influence between Corporate Social Responsibility on tax aggressiveness.

This research is not in line with research conducted by Elmi Rakhma [9], Ida Ayu, Ni Ketut [10] Denny, Akhmad Saebani [11]. The results of this study reveal that there is a significant influence between Corporate Social Responsibility on tax aggressiveness.

\section{The Influence of Corporate Social Responsibility on Tobin's Q \\ The test results state that there is no significant} influence between Corporate Social Responsibility (CSR) on financial performance.

Corporate Social Responsibility or what is commonly referred to as corporate social responsibility is the ability of a company to be able to overcome the negative implications which are the result of the company's production process, company operations and company facilities. One of the ways to overcome the negative implications is to minimize the negative impacts caused by the production process and company operations, maximize company efficiency and minimize negative practices that can affect a country's natural resources for future generations.

If it is related to the stakeholder theory, this has a connection that the government is one of the stakeholders for the company, because the government has an interest in the company's activities and the existence of the company. The existence of bureaucratic rules and regulations applied by the government that must be obeyed by the company creates a relationship between the company and the government. In this case, the size of the tax borne or to be paid by the company indirectly makes the government part of the company's stakeholders.

The results of this study are not in line with research conducted by Marissa Yaparto, Dianne [12], Nita Dwi Aryati [13], Nanik Lestari, Novi [14]. The results of this study reveal that corporate social responsibility affects financial performance.

The results of this study are in line with research conducted by Hari Setyawati \& Yusuf S. Bahar [25] which revealed that there was no influence between disclosure of Corporate Social Responsibility on Profitability.

\section{The Effect of Tax Aggressiveness on Tobin's Q (Financial Performance)}

The test results state that there is no significant influence between Corporate Social Responsibility (CSR) on financial performance.

Corporate Social Responsibility or what is commonly referred to as corporate social responsibility is the ability of a company to be able to overcome the negative implications of the company production process, company operations and company facilities. One of the ways to overcome the negative implications is to minimize the negative impact caused by the production process and company operations, maximize company efficiency and minimize negative practices that can affect a country's natural resources for future generations.

If it is related to the signaling theory, this has a relationship, where the signaling theory focuses on the importance of information contained in the financial statements on investment decisions made by parties outside the company. This information is important for investors and business people because in essence it will provide an overview of the company's past, present and future conditions for the company's survival and its effects on the company. 
The results of this study are not in line with research conducted by Marissa Yaparto, Dianne [12], Nita Dwi Aryati [6], Nanik Lestari, Novi [14]. The results of the study reveal that corporate social responsibility has an effect on financial performance.

The results of this study are in line with research conducted by Hari Setyawati \& Yusuf S. Bahar [25-27] which revealed that there was no influence between CSR disclosure on profitability.

\section{CONCLUSIONS AND RECCOMENDATION Conclusion}

This research was conducted with the aim of knowing the effect of Corporate Social Responsibility on Tax Aggressiveness and its Impact on Financial Performance. Based on the formulation of the problem, testing the hypothesis and the discussion previously presented, the following conclusions can be drawn:

1. Corporate Social Responsibility does not have a significant effect on tax aggressiveness, this is because the company already understands that paying taxes is an obligation for mining companies.

2. Tax aggressiveness has a significant effect on financial performance in a negative direction, meaning that the greater the tax paid, the smaller the company's profits, and vice versa. Tax Aggressiveness and Financial Performance are variables that influence each other, in opposite directions.

3. Corporate Social Responsibility does not have a significant effect on financial performance, this is because Corporate Social Responsibility activities for mining companies are mandatory in accordance with statutory regulations so that they are not sustainable on the company's financial performance.

\section{Recommendation}

Some suggestions that can be considered for further research are:

1. For mining entities / companies Mining companies are expected to increase their Corporate Social Responsibility program activities not only for the environment by reforesting the natural damage that has been done to mining activities, but also to the surrounding community so that the surrounding community can take advantage of the company's existence which in the end will improve the standard of living of the surrounding community and gain legitimacy for the company so that the company's operations become smoother and do not get rejection from the community.

2. For Practitioners of Corporate Social Responsibility

Practitioners are expected in carrying out Corporate Social Responsibility activities, they must think about the continuity of activities in a gradual and sustainable manner that can improve the standard of living both the standard of living of the company's own employees and the standard of living of the surrounding community. Sustainable Corporate Social Responsibility activities will have a positive impact on the surrounding community and also have a positive impact on the company, both in value and in the company's image.

\section{REFERENCES}

1. Fabiola, F. (2019). Corporate Social Responsibility, a Reflection of the Pros and Cons of Company Business. Accessed on 02 March 2020 from the World Wide Web: http://suara.com/yoursay/2019/06/24/120000/corpo rate-social-responsibility-a-company-businessgood-bad-reflection? Page $=$ all

2. Yuansyah, S. (2018). Mining Companies Are Asked To Apply Environmental Corporate Social Responsibility - Vulnerable to Pollution. Accessed on March 2, 2020 from the World Wide Web: http: // http://www.neraca.co.id/article/21817/ miningcompanies requested to apply-csr-environmentvulnerable-pollution

3. Martiono, H. (2018). Mining Corporations Are Not Aware of Social Responsibility. Accessed on January 7, 2019 from the World Wide Web: http: // https://bisnis.tempo.co/read/416524/korporasitambang-tak-sadar- responsibility-Sosial

4. Preuss, S. (2010). Smoke and Mirrors: CSR and Tax avoidance. Accounting Forum, 153-168

5. Faridatul, A.W. (2018). The Influence of Corporate Social Responsibility on Tax Aggressiveness Planning. Journal of Accounting and Business, 18(1)

6. Dwi, F. (2017). The Influence of Corporate Social Responsibility on Tax Aggressiveness Planning. Ejournal Universitas Riau, 12(2)

7. Jessica., \& Agus, A. (2014). The Influence of Corporate Social Responsibility on Tax Aggressiveness Planning. Tax \& Accounting Review, 4(1).

8. Triani, A. (2018). The Influence of Corporate Social Responsibility on Tax Aggressiveness Planning. Journal of Economics, Business and Accounting, 20(1).

9. Elmi, R. (2018). The Influence of Corporate Social Responsibility on Tax Aggressiveness Planning. Journal Accounting and System Information, 3(2).

10. Ida, A., Ni, K. (2018). The Influence of Corporate Social Responsibility on Tax Aggressiveness Planning. E-Journal of Accounting at Udayana University, 23(1).

11. Denny, A.S. (2019). The Influence of Corporate Social Responsibility on Tax Aggressiveness Planning. Widyakala, 6(1).

12. Marissa, Y.D. (2013). The Influence of Corporate Social Responsibility on Financial Performance. 
University of Surabaya Student Scientific Journal March, 9(12).

13. Nita, D.A. (2017). The Influence of Corporate Social Responsibility on Financial Performance. Thesis, Surakarta Muhammdiyah University.

14. Nanik, L.N. (2019). The Influence of Corporate Social Responsibility on Financial Performance. EQUITY Journal of Economics, Management, Accounting, 22(1)

15. Nor, Hadi. (2011). Corporate Social Responsibility. Yogyakarta: Graha Science.

16. Hidayati, M. (2009). The Effect of CSR Disclosure on the Earning Responses Coefficient in High Profit Companies. Journal of Business and Accounting, 2(1)

17. Freeman, R. Edward. (1984). A Survey of Sustainability Reporting Practices of Australian Reporting Entities. Australian Accounting Review, 15(1)

18. Ghozali dan Chariri. (2007). Accounting Theory. Semarang: Universitas Diponegoro.

19. Brigham dan Joel, F. Houston. (2001). Financial Management II. Jakarta. Salemba Empat.

20. Balakrishnan. (2011). Does Tax Aggressiveness Reduce Financial Reporting Transparency? Wharton School. University of Pennsylvania.

21. Frank, M., Lynch. (2009). Tax reporting aggressiveness and its relation to aggressive financial reporting. The Accounting Review, 84, 467-496.
22. Lanis, R., dan G. Richardson. (2013). Corporate Social Responsibility and Tax Aggressiveness: a test of legitimacy theory. Accounting Auditing and Accountability Journal, 26(1).

23. Hlaing. (2012). Organizational Architecture of Multinationals and Tax Aggressiveness. University of Waterloo. Canada

24. Le, T. B., \& Laub, M. T. (2014). New approaches to understanding the spatial organization of bacterial genomes. Current opinion in microbiology, 22, 15-21.

25. Hari Setyawati dan Yusuf S. Basar. (2017). The Effect of Disclosure of Corporate Social Responsibility and Implementation of Good Corporate Governance on the Level of Profitability: An Empirical Study of Mining Sector Companies Listed on the IDX. Accounting Journal, Vol XXI, No.3

26. Halimi, F., \& Waluyo, W. (2019). Pengaruh tax avoidance, penerapan sanksi pajak dan pelayanan perpajakan terhadap kepatuhan wajib pajak (Studi Empiris Pada Wajib Pajak Orang Pribadi di KPP Pratama Jakarta Setiabudi Dua). Jurnal Muara Ilmu Ekonomi dan Bisnis, 3(2), 302-312.

27. O’Donovan, G. (2002). Environmental Disclosures in the Annal Report: Extending the Applicability and Predictive Power of Legitimacy Theory, Accounting, Auditing and Accountability, Vol. 15. 